\title{
Lost in the Heartland: Childhood, Region, and Iowa's Missing Paperboys
}

\author{
PAUL MOKRZYCKI
}

EIGHT-YEAR-OLD ELIZABETH COLLINS and her cousin, ten-year-old Lyric Cook-Morrissey, vanished on July 13, 2012. The two went for a bike ride in what has since been renamed Angels Park in Evansdale, Iowa, and never returned home. Their disappearance triggered massive searches and received considerable local media attention. A group of hunters eventually found their bodies in December of the same year. Their murders devastated the Evansdale community. "They're our girls," one local woman, standing with her children, explained to a reporter. "They're everybody's girls." With the gruesome discovery of the girls' bodies, one news account gestured to the past: "Once again,

The author thanks the State Historical Society of Iowa for its research support, which it provided through a generous grant and through the invaluable assistance of Sharon Avery and others at its Des Moines archives. Marvin Bergman offered kind words and constructive criticism at each stage of the research, writing, submission, and publication process. Special thanks go to Donna Smith and Dave Busiek at KCCI-TV; to the folks at Anderson-Erickson Dairy; and to Eric Leong, Wartburg College, and David McCartney, University of Iowa Archivist, for research assistance at the Archives of Iowa Broadcasting at Wartburg College. The astute comments of three anonymous readers proved beneficial while preparing the essay for publication. Finally, this project would not have been possible without the support and guidance of Landon R. Y. Storrs, Shelton Stromquist, Colleen Davis, John Kelly, Kelsey Potdevin, Allison Wells, Eric S. Zimmer, Pam Stek, Jake Altman, Katrina Rose, Pat Goodwin, Sheri Sojka, Blake Barton Renfro, Aleksander Mokrzycki, and Bo Nyk.

THE ANNALS OF IOWA 74 (Winter 2015). (C) The State Historical Society of Iowa, 2015. 
Iowa lost more of its innocence." 1 The following summer, another disappearance and slaying-this time of 15-year-old Kathlynn Shepard from Dayton, Iowa - rocked the state. "This is a safe community," an area mother contended after the Shepard tragedy. "This kind of thing should not happen. It's unfathomable." Another woman from Dayton lamented, "It's a small community and we're hurting." The county sheriff shared these women's concerns, commenting, "We were robbed of some innocence in this whole thing. We'll never quite be the same." 2

These cases brought a specific type of trauma to these Iowa communities, one that journalists, law enforcement officials, and ordinary people found all too familiar. The Evansdale and Dayton incidents spurred numerous comparisons to the unsolved disappearances of Des Moines paperboys Johnny Gosch in 1982 and Eugene Wade Martin in 1984. A 2012 newspaper article, for instance, remarked on the similarities between the Gosch episode and that of the Evansdale cousins. "Both cases involved children doing the activities children are supposed to do without worry: Gosch was delivering newspapers around his neighborhood," while the young girls "were riding their bicycles on a hot summer afternoon." The same account touched on the Gosch case as a moment of fracture, much as the Evansdale and Dayton tragedies had been for their communities. ${ }^{3}$

For many Iowans, Gosch's disappearance represented a loss of innocence; it imposed new strictures on childhood and parenthood while casting a pall on the midwestern idyll. "It's not the type of crime that happens in Iowa," the Des Moines Register reported. An interviewee concurred. "There were kidnappings but it was never kids, at least not that we'd seen in our lives. We were

1. Alison Gowans, "'Dancing Up with Our Savior': Iowa Mourns the Missing Cousins of Evansdale," Cedar Falls Patch, 12/9/2012; Emily Schettler, "Bodies Confirmed to Be Missing Iowa Cousins," Des Moines Register (hereafter cited as DMR), 12/11/2012.

2. Barbara Rodriguez, "Iowa Residents Saddened Body Could Be Missing Girl," Associated Press (hereafter cited as AP) news release, 6/8/2013. Police believe a 42-year-old convicted sex offender named Michael Klunder abducted and murdered Shepard. Authorities have also implicated Klunder in the slayings of Elizabeth Collins and Lyric Cook-Morrissey, although that case remains open.

3. Emily Schettler, "Living without Answers," DMR, 9/4/2012. For more on "fracture" as a defining feature of late twentieth-century political culture, see Daniel T. Rodgers, Age of Fracture (Cambridge, MA, 2011). 
all raised watching the Andy Griffith Show and Leave It to Beaver, and these things didn't even occur to us. That was the most bothersome thing was that this kind of stole our innocence from us." Another report struck a similar chord. "We still remember the names. Their faces. Details of their disappearances. Johnny Gosch, 12. Vanished nearly 30 years ago while delivering newspapers. Eugene Martin, 13. Went missing 28 years ago.... Now two more Iowa children have disappeared. And like the others, their names are etched on the hearts of Iowans. . . Lyric Cook-Morrissey, 10. Elizabeth Collins, 8." 4 The Gosch and Martin cases occurred just as the issue of "missing children" began to coalesce in the American political consciousness. But those mysteries, more so than other famous missing children cases of the late 1970s and 1980s, remain metaphorically linked to the state in which they transpired.

This article explores the Gosch and Martin disappearances what they meant for Iowans and other midwesterners and how they have shaped the national political discourse about missing children since the 1980s. These incidents shattered notions of "innocence" in the midwestern political imagination. Parents, child welfare advocates, media representatives, and public officials contended that the Gosch and Martin cases signaled a shift away from safety, order, and idealized childhood and toward chaos, criminal depravity, and imperiled childhood. The incidents provoked responses rooted in notions of midwestern communitarianism, pastoralism, and virtue. The political and rhetorical responses to these high profile cases indicate how notions of regional innocence intersected with broader national concerns animating the conservative counterrevolution. The Gosch and Martin tragedies helped advance arguments about pornography, crime, prostitution, law enforcement ineptitude, homosexuality, religious cultism, and other forces ostensibly antagonistic to the "traditional" American family. Such arguments stemmed from and grounded larger anxieties about familial and, by extension, national decline. ${ }^{5}$ This article focuses on these responses and

4. Schettler, "Living without Answers"; idem, "FBI Believes Girls Are Alive," $D M R, 7 / 22 / 2012$.

5. For more on these hallmarks of midwestern identity, at least as they appear in the popular imagination, see Victoria Johnson, Heartland TV: Prime Time Television and the Struggle for U.S. Identity (New York, 2008); James H. Madison, ed., 
their political salience while providing a narrative overview of the paperboy cases and their role in the national missing children campaign of the 1980s.

The Midwest is often constructed and construed, both within and beyond the region, as America writ small. Iowa, for one, is commonly the butt of jokes regarding American "averageness" or "typicality." 6 Test marketers flock to the Midwest because of its reputation as "the most American region." They believe that "if a product will sell in Des Moines or Columbus," one historian observes, "it will sell anywhere." 7 Politicians, too, understand the cachet of the "heartland" as a site of "Americanness" and traditional virtue. ${ }^{8}$ Political commentator Thomas Frank contends that, at least in the popular imagination, contemporary conservatism has become "the faith of the hardworking common people of the heartland, an expression of their unpretentious, all-American ways just like country music and NASCAR." 9 It is both possible and fruitful to probe the political meanings of such ideas without accepting the problematic notion that the Midwest is, in fact, an "innocent" site. 10

Just as the Midwest functions in the political consciousness as a space of pure "Americanness," the region also serves as the "normative" site of American childhood. The historical construc-

Heartland: Comparative Histories of the Midwestern States (Bloomington, IN, 1988); and James R. Shortridge, The Middle West: Its Meaning in American Culture (Lawrence, KS, 1989).

6. The satirical newspaper the Onion takes goodhearted aim at Iowa with some regularity. See, for example, "Iowa Fashion Week Begins," Onion, 3/11/2013.

7. R. Douglas Hurt, “Midwestern Distinctiveness," in The American Midwest: Essays on Regional History, ed. Andrew R. L. Cayton and Susan E. Gray (Bloomington, IN, 2001), 173.

8. See, among others, Shortridge, The Middle West; Jon K. Lauck, The Lost Region: Toward a Revival of Midwestern History (Iowa City, 2013); and Frank Tobias Higbie, "Heartland: The Politics of a Regional Signifier," Middle West Review 1 (2014), 84-90. Too few historians have examined the particularities of midwestern political culture in the late twentieth century. While this article seeks to rectify this elision, it is important to recognize the difficulties inherent in defining a region and assigning it distinctive characteristics without essentializing.

9. Thomas Frank, What's the Matter with Kansas? How Conservatives Won the Heart of America (New York, 2004), 20.

10. For studies of Iowa that cast the state as "typical," see Joseph Frazier Wall, Iowa: A Bicentennial History (New York, 1978); and Dorothy Schwieder, "Iowa: The Middle Land," in Heartland, ed. Madison, 276-96. 
tion of childhood innocence reifies and reflects existing indicators of privilege along racial, class, and gendered lines. As white paperboys from middle-class midwestern suburbs, Johnny Gosch and Eugene Martin epitomized boyhood innocence and vulnerability. In fact, they became the literal pictures of boyhood innocence and vulnerability as the first missing children featured on milk cartons. One literary theorist describes how "children, as an idea, are likely to be both white and middle-class." In her rendering, it is "a privilege to need to be protected - and to be sheltered-and thus to have a childhood. Not in spite of privilege, then, but because of it, the all-important feature of weakness sticks to these markers (white and middle class) and helps to signal innocence." 11 Gosch and Martin fit within this model and add new wrinkles to it. For many midwesterners, their disappearances symbolized not just physical losses, but also the losses of innocence, childhood, whiteness, middle-classness, and midwesternness.

AT ABOUT SIX O'CLOCK on the Sunday morning of Labor Day weekend in 1982, Johnny Gosch and a fellow paperboy picked up their allotment of newspapers from the United Methodist Church in West Des Moines. Gosch, a husky, freckled 13year-old with a mop of light brown hair, departed the church with his friend, and they diverged on their respective routes. Johnny's dachshund, Gretchen, walked beside him. Soon after the boys left the church, Gosch's fellow carrier recalled, "a man wearing a baseball cap and driving a dark blue car ... asked both boys, in separate conversations" for directions to the same location. The other paperboy, "whose frightened mother asked that his name not be used" in newspaper accounts, saw Johnny speaking to a man near the intersection of 42nd Street and Marcourt Lane. In the predawn darkness, the young carrier could not determine whether it was the same man who had asked for directions earlier. An adult neighbor corroborated the boy's version of events, confirming that he, too, had provided directions to a man in a blue car. There is little agreement about what happened next. Some insist that a man followed Johnny around a street corner

11. Kathryn Boyd Stockton, The Queer Child, or Growing Sideways in the Twentieth Century (Durham, NC, 2009), 31 (emphasis in original). 
before snatching him and whisking him away. Others say they heard a car door slam and tires screech before witnessing a vehicle run a stop sign and travel north toward Interstate 235 "at a high rate of speed." The Gosches' dachshund returned home without Johnny, and his father found the boy's wagon still full of newspapers two blocks from the family's home. ${ }^{12}$

The Gosches initially applauded the law enforcement response to Johnny's disappearance. One newspaper report indicated that 25 to 30 area law enforcement officials participated in searches for Johnny within a few hours of his disappearance. A television news segment stated that 40 city police officers, Polk County sheriff's deputies, and state highway patrolmen engaged in searches on that Sunday. The following day-Labor Day-Boy Scouts, sheriff's deputies, other law enforcement authorities, and approximately 1,000 volunteers scoured the area for Johnny's body or any clues that might lead to his recovery. The "somber searchers," as the Des Moines Register characterized them, "anxiously" combed through "woods and parks, fields and ditches," vacant lots, and apartment buildings, but ultimately found nothing. John Gosch, Johnny's father, expressed his confidence in the West Des Moines police force, calling their work "fantastic" and observing, "They are working overtime like I've never seen anybody in my life work before."13 Yet the official investigation yielded few leads in the days following Johnny's disappearance - or ever since. Police publicized their search for two vehicles: a "blue over blue" full-size car with Warren County, Iowa, license plates and a silver late-model Ford Fairmont with a large black stripe at the bottom. The Iowa Division of Criminal Investigation (DCI) shortly thereafter announced that it had discovered a photograph depicting a Ford Fairmont similar to the one spotted at the scene of the disappearance. ${ }^{14}$

12. KCCI-TV, CBS affiliate, Des Moines (hereafter cited as KCCI-TV), 9/5/1982; Carol Pitts, "Police Hunt for Missing W.D.M. Boy," DMR, 9/6/1982; Noreen N. Gosch, Why Johnny Can't Come Home (West Des Moines, 2000), 3; Missing Johnny, MSNBC documentary, originally aired 12/23/2012.

13. Pitts, "Police Hunt for Missing W.D.M. Boy"; Carol Pitts, " 1,000 Volunteers Search for Missing W.D.M. Boy," DMR, 9/7/1982; KCCI-TV, 9/5/1982, 9/6/ 1982, 9/7/1982.

14. Pitts, "1,000 Volunteers Search for Missing W.D.M. Boy"; KCCI-TV, 9/6/1982. 
Authorities never located either vehicle, however, thereby stoking the ire of Johnny's parents and shaking their confidence in the investigation. One month after their son went missing, the Gosches publicly articulated their frustrations with the police: first, for their insistence that the Gosches submit to polygraph testing and, second, for their inability to find what John Gosch called two "distinctive" automobiles. The relationship between the Gosches and law enforcement officials deteriorated from there. Johnny's mother, Noreen, soon cultivated a vigilante ethos that she has deployed ever since. In October she called the office of Iowa Governor Robert D. Ray and left a message with his administrative assistant. The secretary's handwritten note read, "There is a 'white-washing' job being done as far as what is being done ... considering class action suit because of ways [the case is] being handled. Wants someone with 'clout' to [oversee] their file." Noreen Gosch phoned Governor Ray at least once more in 1982 to cast aspersions on the police investigation and express her disdain for conventional law enforcement methods. The Gosches' distrust of authority, coupled with their belief that "the police ha[d] reached a dead end," pushed the couple to seek the assistance of private investigators. ${ }^{15}$ Their antagonism culminated in a spate of public feuds with the Federal Bureau of Investigation (FBI) and other law enforcement entities throughout the 1980s and into the 2000s.

LOCAL LAW ENFORCEMENT OFFICIALS had few leads to pursue and no concrete evidence to suggest that Gosch had been abducted. Still, both the Gosches and the authorities seemed ready to negotiate with Johnny's supposed captors. The day after Johnny vanished, a television reporter for KCCI in Des Moines asked DCI agent Gene Meyer if the authorities would have usually received a call from the kidnappers by that point, to which Meyer replied, "Normally, yes." His response suggests that

15. KCCI-TV, 10/7/1982; “While You Were Out," written message from Noreen Gosch transcribed by an assistant for Gov. Robert D. Ray, n.d., folder 21, 532/5/7, John Gosch-disappearance, 1982, box 7, Departmental and Subject Files, Governor Robert D. Ray Papers, State Historical Society of Iowa, Des Moines (hereafter cited as SHSI-DM); Personal notes, Gov. Robert D. Ray, n.d., ibid.; Frank Santiago, “Gosches Refuse Lie-Detector Tests,” DMR, 10/8/1982. 
authorities either did not believe that Johnny had been abducted or that his case would not involve a ransom. Two days later, Gosch's parents made a direct televised appeal to the purported abductors. Noreen assured the kidnappers that the family would "meet their demands" and provided a telephone number that she guaranteed would connect to a live operator 24 hours a day. ${ }^{16}$

Ransom kidnappings, especially of children, had periodically riveted the American public since the late nineteenth century. By the early 1980s, though, the phenomenon was being supplanted by a focus on "missing children," a term popularized in 1981 that the Department of Justice later codified to include lost, abducted, runaway, and "thrownaway" youths. ${ }^{17}$ Although many different types of cases fit under the missing children umbrella, media accounts and political rhetoric fixated on the rarest of those episodes: kidnappings by "strangers." Some journalists, child welfare advocates, and public officials insisted that strangers took 50,000 youths from their homes annually. ${ }^{18}$ In reality, only a few hundred young Americans, at most, were snatched in any given year

16. KCCI-TV, 9/6/1982, 9/8/1982.

17. These categories received extensive attention in various congressional hearings held in the 1980s. A more rigid and well-defined taxonomy appeared in subsequent Department of Justice studies on the incidence of missing children. See, among others, U.S. Congress, Senate, Committee on the Judiciary, Exploitation of Children: Hearing before the Subcommittee on Juvenile Justice, 97th Cong., 1st sess., 11/5/1981; U.S. Congress, House of Representatives, Committee on the Judiciary, Missing Children's Act: Hearings before the Subcommittee on Civil and Constitutional Rights, 97th Cong., 1st sess., 11/18/1981 and 11/30/1981. The National Incidence Studies of Missing, Abducted, Runaway, and Thrownaway Children (NISMART), mandated by the federal Missing Children's Assistance Act of 1984, offer the most comprehensive statistical overviews of the missing children issue. The Office of Juvenile Justice and Delinquency Prevention published two such studies in 1988 (NISMART-1) and 1999 (NISMART-2). Both downplayed the severity of "stranger abductions," which had captured national headlines in the early 1980s. From NISMART-2: "Stereotypical kidnappings are the particular type of nonfamily abduction that receives the most media attention and involves a stranger or slight acquaintance who detains the child overnight, transports the child at least 50 miles, holds the child for ransom, abducts the child with intent to keep the child permanently, or kills the child." For more, see U.S. Department of Justice, Office of Juvenile Justice and Delinquency Prevention, NISMART, "National Estimates of Missing Children: An Overview," Oct. 2002, ncjrs.gov/pdffiles1/ojjdp/196465.pdf, accessed 9/14/2013.

18. See, for example, "Protecting Kids: A Matter of Growing Concern," Time, 11/18/1985. 
by someone they did not know. ${ }^{19}$ As historian Paula Fass has illustrated, fears about the sexual exploitation of young Americans by strangers, although implicit in many earlier child kidnapping cases, dominated the discourse surrounding missing children in the late twentieth century. ${ }^{20}$ That local law enforcement seemed reticent to call Gosch's disappearance a kidnapping and that the Gosches still hoped to negotiate with their son's alleged captors suggest an uncertainty about the case rooted in the historical milieu - in which fears about "missing children" were just beginning to gain currency - and the regional context. More specifically, the notion that a sexually or otherwise nefariously motivated abduction of a child "couldn't happen here," in the seemingly secure suburb of West Des Moines, remained firmly entrenched in the minds of many Iowans.

The confusion and disbelief surrounding the Gosch case no doubt made Iowa parents and children anxious. Just a few days after Johnny went missing, Noreen observed "how many mothers were stationed along the way, escorting their children home" from school. She affirmed that Johnny's disappearance had "created a sense of panic in people, and rightly so." 21 This collective tension appeared even more plainly the next Sunday, as young paper carriers set out on their routes amid drastically heightened security. Police established checkpoints around the site where Johnny had vanished, questioning motorists and looking for any suspicious activity. Many parents accompanied their children as

19. NISMART, "National Estimates of Missing Children."

20. Paula S. Fass, Kidnapped: Child Abduction in America (Berkeley, CA, 1997). Most child abduction cases do not involve a sexual motive. See James N. Tedisco and Michele A. Paludi, Missing Children: A Psychological Approach to Understanding the Causes and Consequences of Stranger and Non-Stranger Abduction of Children (Albany, NY, 1996). For more scholarship on the missing children phenomenon, most of which takes a decidedly quantitative approach, see Martin L. Forst and Martha-Elin Blomquist, Missing Children: Rhetoric and Reality (New York, 1991); Joel Best, Threatened Children: Rhetoric and Concern about Child-Victims (Chicago, 1990); Noah J. Fritz and David L. Altheide, "The Mass Media and the Social Construction of the Missing Children Problem," Sociological Quarterly 28 (1987), 473-92; Cynthia Gentry, "The Social Construction of Abducted Children as a Social Problem," Sociological Inquiry 58 (1988), 413-25; Karen Ann Joe, "Milk Carton Madness: The Heart of the Missing Children's Crisis" (Ph.D. diss., University of California-Davis, 1991).

21. KCCI-TV, 9/9/1982. 
they delivered papers. The Des Moines Register, furthermore, kept tabs on its 2,000 young carriers, conducting periodic checks on their routes and issuing emergency whistles to each of them. A television report featured a representative from the paper as he tried to reassure the public, and especially the families of young Register carriers, about the safety of paperboys and girls. "We're very, very concerned about creating some unnecessary panic amongst our carriers, and I hesitate to use the word 'panic,' but we don't want to unnecessarily scare a carrier." He continued, "Newspaper work traditionally has been a good learning experience for young people, and this is an unfortunate situation. It's the first [child carrier abduction] that I'm aware of in the Des Moines area." The spokesman aimed to restore community members' faith not only in the Register itself, but also in the security of young carriers and their romanticized tradition of paper delivery. Gosch's disappearance was an aberration, he reminded viewers, one that did not warrant any "unnecessary panic." 22

Yet the increasing attention paid to Johnny Gosch in the state and nationwide convinced many Iowans that his case was not unusual but rather part of a national epidemic that until then had not presented itself in Iowa. The Gosches and others invested in their son's case harnessed the rhetoric and moralistic tenor of the missing children movement while couching that language in conceptions of midwestern exceptionalism. After Johnny vanished, Candy Gilchrist formed a Des Moines chapter of Child Find, Inc., a national organization founded in 1980 in New Paltz, New York. In a press release she noted, "People don't want to believe that these things happen in little Iowa." 23

John and Noreen Gosch involved themselves in local and national organizing related to the missing children campaign. They established the Johnny Gosch Foundation, alternately called Help Find Johnny Gosch, Inc., within two months of their son's disappearance. ${ }^{24}$ Under the auspices of that organization, the Gosches raised funds to help pay for private detectives, hosted

22. KCCI-TV, 9/12/1982.

23. AP, “Gosch Case Is Just One of 150,000,” DMR, 11/21/1982.

24. Gosch, Why Johnny Can't Come Home, 14. 
bimonthly group gatherings at their home, and convened large seminars and town hall meetings within and beyond Iowa. 25

Earlier child abductions in the Des Moines area had received significant press coverage, but they did not signal a larger social problem or regional crisis as Gosch's case did. On Christmas Eve, 1968, 10-year-old Pamela Powers was kidnapped from the Des Moines YMCA, raped, and murdered by Robert Anthony Williams, a fugitive from an area mental hospital. Williams surrendered to police two days later in Davenport, about 170 miles east of Des Moines. As the authorities transported him back to Des Moines, he directed them to Powers's body. Defense attorneys argued that the information Williams furnished during the car ride to Des Moines could not be admitted as evidence; the judge disagreed, and the jury at the subsequent trial found Williams guilty of first-degree murder. The Iowa Supreme Court upheld the decision, but the U.S. Supreme Court did not. In Brewer v. Williams (1977), the high court overturned Williams's conviction on the grounds that detectives had denied Williams his right to counsel, "used psychological coercion," and violated explicit instruction "not to interrogate Williams without his attorney present." 26 The murder and the judicial wrangling it prompted generated substantial attention in the Register and elsewhere, but the media focused primarily on the legal dimensions of the case, not the broader threats the tragedy might have represented. Likewise, the 1973 disappearance of an 11-year-old Boy Scout named Guy Heckle from Cedar Rapids - the oldest active unsolved missing persons case in Iowa-had garnered much less press coverage than Gosch and Martin's. ${ }^{27}$ Even though Heckle van-

25. See, for example, KCCI-TV, 2/4/1983; KGAN-TV, 5/18-22/1984, clip no. 238, Archives of Iowa Broadcasting, Wartburg College, Waverly, Iowa (hereafter cited as AIB).

26. Brewer, Warden v. Williams, no. 74-1263, 430 U.S. 387, 97 S. Ct. 1232, 3/23/1977; Robert M. Regoli and John D. Hewitt, Exploring Criminal Justice: The Essentials (Burlington, MA, 2010), 134; Mara Bovsun, "Bury Her for Christmas: How the Murder of Pamela Powers, 10, Reached the Supreme Court," New York Daily News, 12/16/2012; Mark Brown, "Fugitive from Mental Hospital Charged in Murder of Iowa Girl, 10," Gettysburg (PA) Times, 12/27/1968.

27. For a list of missing persons in Iowa administered by the state's Department of Public Safety (DPS), beginning with Boy Scout Guy Heckle in 1973, see the Missing Person Information Clearinghouse, Iowa DPS, iowaonline.state.ia.us/ mpic/Controller.aspx, accessed 12/24/2013. 
ished in a year of profound national turmoil, his disappearance did not seem to alert Iowans to a larger national problem. ${ }^{28}$ On the other hand, media treatment of Gosch's case referred to the boy as "a statistic, one of 150,000 children who disappear each year" in the United States, and a "unique statistic" at that: "the only Iowa child who is believed to have been abducted and who is still missing." 29

As Johnny's invisibility became more visible, the missing boy began to serve as a cautionary tale in Iowa and a symptom of a regional crisis. He became the basis upon which adults taught youngsters about safety and a phantom upon which they projected their fears. Campaigns to fingerprint children cropped up around the country in the early 1980s. Gosch's disappearance directly informed such efforts in Iowa. A Register article from 1983 alluded to the Gosch case as it covered a fingerprinting drive in Ames, hosted by the city's police department and the Iowa State University Air Force ROTC. The volunteers in Ames fingerprinted some 500 children at the event. In March 1983 the small town of Conrad, Iowa, with a population of just 1,133 in 1980, sponsored the fingerprinting of 200 children, according to a television news report. The TV piece referred to the Gosch incident as evidence of the purportedly "rising number" of youth kidnappings and the idea that such atrocities "can happen anywhere." Similarly, the Des Moines police department and the city's PTA council joined forces with local public and private schools in April 1983 "to provide a uniform identification system to assist law enforcement agencies in locating lost, missing, or abducted children." The fingerprinting program, dubbed K.I.D.S. (Kids

\footnotetext{
28. For more on 1973 as a watershed year, see Andreas Killen, 1973 Nervous Breakdown: Watergate, Warhol, and the Birth of Post-Sixties America (New York, 2006); Thomas Borstelmann, The 1970s: A New Global History from Civil Rights to Economic Inequality (Princeton, NJ, 2011); Benjamin C. Waterhouse, "Mobilizing for the Market: Organized Business, Wage-Price Controls, and the Politics of Inflation, 1971-1974," Journal of American History 100 (2013), 454-78. For more on Heckle, see Jeff Burnham, "Murdered. Missing. Unsolved. [series]: 2 Iowa Boys Gone but Not Forgotten," Cedar Rapids-Iowa City Gazette, 3/20/1992; Cindy Hadish, " 'Not Knowing Is Hard,' " Cedar Rapids-Iowa City Gazette, 7/24/ 1995; Steve Gravelle, "How Did Guy Die?" Cedar Rapids-Iowa City Gazette, 2/3/ 2002.
}

29. AP, “Gosch Case Is Just One of 150,000.” 
Identification and Description System), was offered to approximately 21,000 children enrolled in kindergarten through sixth grade in the Des Moines area. ${ }^{30}$

Such initiatives and the attitudinal shifts that activated them exacerbated Iowa children's anxieties about kidnappings and safety more generally. A 1983 survey of 500 first, third, and fifth graders in Des Moines elementary schools exposed the children's concerns about death, safety, and other, more mundane matters. Sixty-three percent of respondents said they "worry about the safety of their neighborhood," a figure that local researcher and guidance counselor Jan Kuhl attributed to the Gosch case. ${ }^{31}$ In order to ameliorate some of these tensions, the Des Moines Register started a "carrier safety program," called Homes Offering a Protective Environment (H.O.P.E.), "designed to tell carriers and parents what they can do to prevent or respond to dangerous situations." The Register project designated certain homes as "safe" spaces "where carriers can seek assistance." 32 The Register's circulation director, Mike Murray, denied the project's "direct" relationship "to the mysterious disappearance of Johnny Gosch," perhaps in order to defend the paper from charges of negligence or culpability in the Gosch case. ${ }^{33}$

In September 1983, when 13-year-old paperboy Danny Joe Eberle went missing delivering the Sunday Omaha World-Herald in the suburb of Bellevue, Nebraska, many speculated that his

30. Willis David Hoover, "Kids' Fingerprinting Makes Mark," DMR, 2/20/1983; KGAN-TV, 3/23-29/1983, clip no. 249, AIB; Tom Alex, "D.M. Students Are First to Get Fingerprinted," DMR, 4/6/1983.

31. Mark Horstmeyer, "What Worries Our Kids," DMR, 5/26/1983.

32. The "safe space" prong of the H.O.P.E. program resembled earlier efforts in Atlanta - as it struggled to address a rash of child abductions and murders from 1979 to 1981 - and in Chicago, Oakland, and other urban centers as they grappled with crime and unrest in the "law and order" sixties and seventies. See Memorandum, Jaci M. Vickers to Lee P. Brown, 6/1/1981, box 177, MS 509, Series I: Office Files (1960-2004), Lee P. Brown Papers, Woodson Research Center, Fondren Library, Rice University, Houston (hereafter cited as LPB); “ ‘Block Parents' to Aid Hyde Park Children," Chicago Tribune, 2/4/1968; Stephen Crews, "Gary Anti-Crime Group Receives Official Support," Chicago Tribune, 8/25/1968; "Hand Symbol to Aid Young in Distress," Chicago Tribune, 11/20/1966; Joy Baim, "'Helping Hands' Aid Waukegan Pupils," Chicago Tribune, 1/8/1967; "Children Get Help from Block Parents," Oakland (CA) Post, 2/19/1970.

33. "News Carrier Program Is Set," DMR, 5/17/1983. 
disappearance was related to Gosch's. Herb Hawkins, special agent in charge of the FBI in Iowa and Nebraska, saw Eberle's disappearance as a potential break in the Gosch investigation. "When I heard [Eberle] was missing, the first thing I thought of was the Gosch case," Hawkins recalled. "I thought at that point we could solve the Gosch case at the same time. The circumstances and the modus operandi were so close to the Gosch case. They were paper boys. Their looks were almost identical." Hawkins's observation about the boys' similar appearances suggests a sexual motive in both cases, although no evidence of molestation ever emerged. The print media also speculated about the possibility of sexual abuse. Two Iowa DCI agents assigned to the Gosch case joined the Eberle investigation to determine whether a connection existed between the two incidents, but no link ever materialized. ${ }^{34}$

Just days after Eberle vanished, a search party discovered his body in a ditch "some three miles from where he disappeared." The Eberle case caused four young carriers with the Des Moines Register, likely already shaken by the Gosch incident one year earlier, to quit their positions. Murray, the Register's circulation director, vowed to "step up" the newspaper's H.O.P.E. initiative in the wake of the Eberle tragedy, and the Omaha World-Herald contacted the Register to inquire about instituting a similar program. Another kidnapping and slaying of a 12-year-old suburban Omaha boy in December invited further comparisons to Gosch's case, but law enforcement denied any such linkage. Still, the Register took special interest in the Omaha incidents and emphasized, as it had with the Gosch case, the middle-class and midwestern serenity they shattered. "In less than three months," one article read, "13-year-old Danny Joe Eberle and 12-year-old Christopher Paul Walden were abducted from the streets of peaceful middle-class Omaha suburbs a few miles apart, and killed." A 20year-old Air Force pilot was arrested and convicted for the abductions and slayings of Walden and Eberle, but authorities de-

34. Gabriella Stern, "Mrs. Gosch: Iowa Errors Helped in Sarpy," Omaha WorldHerald, 3/4/1984; Frank Santiago, "Hideous Picture of Killer Emerging," DMR, 12/11/1983; "Omaha Carrier Disappears," DMR, 9/19/1983; Frank Santiago, “'Several Leads' in Case of Missing Paper Carrier," DMR, 9/21/1983. 


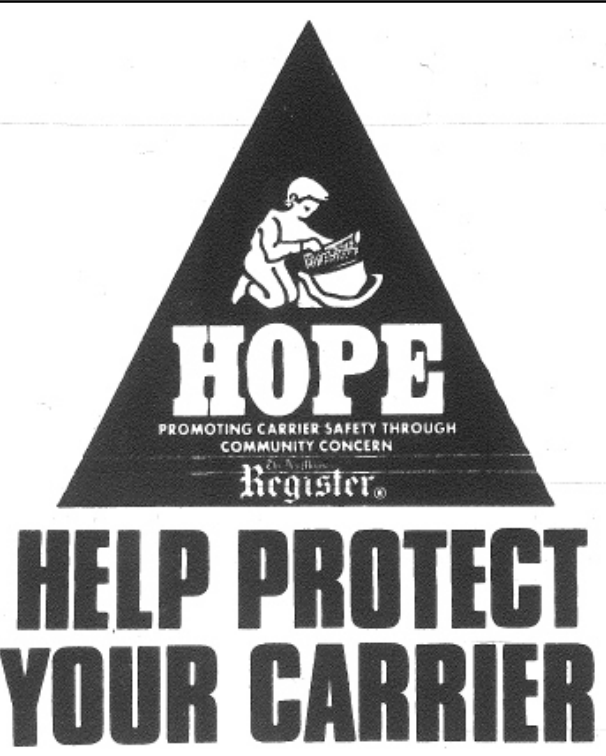

Please help protect your carrier . . . become a part of H.O.P.E. H.O.P.E. (Homes Offering a Protective Environment) is a year-old program designed to help Des Moines Register newspaper carriers who encounter trouble on their routes. At present we need mo. 2 H.O.P.E. households.

When you become a H.O.P.E. home, you'll receive a decal to display in your window. And, you'll get instructions to follow in the event a carrier needs to come to your home in an emergency situation.

All that's required of you is to get help for a carrier in an emergency.

To get an application for the H.O.P.E. program, complete and mail the coupon below. Or call 284-8572 or TOLL FREE 1-800-532-1573 ext. 8572 .

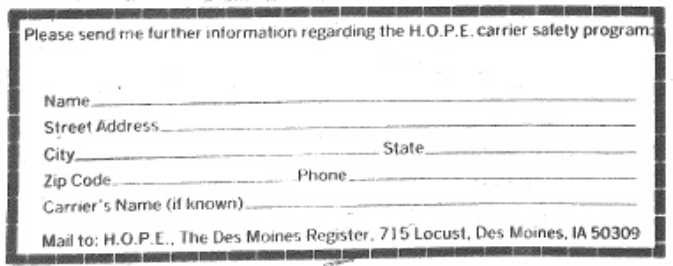

1

After Johnny Gosch disappeared, the Des Moines Register established a "carrier safety program" called Homes Offering a Protective Environment (H.O.P.E.). The initiative encouraged subscribers to sign up and designate their homes as "safe" spaces "where carriers can seek assistance" in the event of an emergency. The Register intensified efforts to keep its young paper carriers secure after Eugene Wade Martin went missing. This advertisement for the H.O.P.E. program appeared in the Des Moines Register, August 22, 1984. Courtesy of Des Moines Register and Register Media. 
termined that the airman had not been in the Midwest in September 1982 when Gosch disappeared. ${ }^{35}$

ALTHOUGH POLICE DETECTIVES ultimately rejected any relationship between the Gosch and Omaha episodes, ordinary Iowans - and Nebraskans -imagined the cases as moments of disjuncture that challenged their basic assumptions about midwestern innocence and security. As white paperboys from middleclass families, Eberle and Gosch personified midwestern boyhood, and many residents of the region perceived their disappearances as assaults on their communities. One woman from Goldfield, Iowa, wrote to the Register to express her frustration with the Eberle case: "I was angry and concerned at the abduction of Danny Eberle in Omaha. . . . Needless to say, my family was deeply affected [by the incident].... There are so many parents, in Iowa alone, concerned with the problem." She went on to advocate school programs "to inform our children and the public what they should do to avoid, prevent or reduce the risks they face as potential victims of abduction, molestation and other crimes committed against children." 36

In response to such concerns, staff members at Midlands Community Hospital in Papillion, near Omaha, devised a program "to provide advice to parents dealing with children's fears stemming from the killings of Christopher Paul Walden and Danny Joe Eberle." The lead nurse urged parents "not to minimize their children's fear" because "their fears are realistic," despite the infrequency of child kidnappings. Residents of tiny Carter Lake, Iowa, along the Iowa-Nebraska border, first proposed creating a youth "protection group" in their self-described "peaceful little town" after Johnny Gosch disappeared, and the

35. Frank Santiago, "No Suspects in Massive Search for Nebraska Newsboy's Killer," DMR, 9/23/1983; idem, "Hideous Picture of Killer Emerging" (emphasis added); idem, "Airman Charged in Omaha-Area Slayings," DMR, 1/13/1984; idem, "Gosch, Slayings Not Related," DMR, 1/18/1984.

36. Charlene Zatloukel, letter to the editor, DMR, 10/19/1983; Alice Noble, "Missing Paperboys Prompt Carrier Protection Programs," United Press International press release, 9/25/1983. 
Eberle and Walden incidents generated a "surge of public sentiment" in favor of such a "public patrol program." 37

Anxieties related to the Eberle and Gosch cases also shaped the lives of paperboys outside of Omaha and Des Moines. A Cedar Rapids television news broadcast aired in October 1983, about a month after authorities found Eberle's body, detailed an encounter in Brighton, Iowa, between an 11-year-old paperboy and a "strange man" in a green pickup truck. The man allegedly attempted to lure the young carrier into his vehicle, but the boy darted away. The boy kept his paper route but admitted that he was "scared," especially when passing the area where the man in the truck had accosted him. ${ }^{38}$

The emphasis on abnormality, specifically regarding "strange" or "weird" men, recurred in rhetoric surrounding the Gosch and Martin cases. On the morning Johnny went missing, he apparently told two witnesses regarding the suspicious man in the blue car, "That man is really weird." 39 In the 30 years since the disappearance, Noreen Gosch has regularly evoked the image of the "weird man." 40 Another individual, referred to in newspaper reports as the "mystery man," phoned the Gosch parents on November 22, 1982, and told them that he "gave Johnny a lift from Des Moines to Atlantic," a small town in Cass County, Iowa. Authorities soon ascertained that the man had lied about giving Johnny a ride; he had "called because he said he felt sorry for the parents." 41

In the early months of the investigation, moreover, Noreen Gosch implicated a religious cult in Johnny's disappearance. ${ }^{42}$ She targeted a group called The Way International, which had allegedly mailed literature to the Gosches in the months before

37. James Ivey, “Slayings Bring Nightmares, Sleeplessness," Omaha World-Herald, 12/19/1983; Gary Newman, "Carter Lake Takes Steps to Prevent Child Abductions," Omaha World-Herald, 12/8/1983.

38. KGAN-TV, 10/19/1983, clip no. 163, AIB.

39. Frank Santiago, “Gosch Talk with 'Weird' Man Told,” DMR, 11/25/1982.

40. See, for example, Gosch, Why Johnny Can't Come Home, esp. p. 3.

41. Frank Santiago, "Officials Clear Gosch 'Mystery Man,'” DMR, 1/5/1983.

42. AP, "News in Brief: Missing Boy," Oelwein Daily Register, 9/22/1982. See also United Press International, "2nd Boy's Disappearance Fuels Gosch Hunt," Chicago Daily Herald, 9/3/1984; Charles Bullard, "Mother Fears Missing Son Abducted by Religious Cult," DMR, 9/22/1982. 
Johnny went missing. In Noreen's telling, The Way contacted Johnny preceding his disappearance and triggered in him a slight personality change. He became more of a contrarian, she asserted, a week or so before he vanished. The Way denied the charges and resented being called a "cult." One representative dismissed Noreen Gosch's accusations as "ridiculous" and maintained that the group adhered to conventional religious doctrine. "We're not a cult," the spokesman avowed. "A cult conjures up thoughts of Jonestown, Charlie Manson, Hitler. ... We believe that the Bible is where it's at." 43

The theme of deviance also appeared in Noreen Gosch's subsequent criticism of pornography, child prostitution, and what she called "homosexual groups." In particular, Noreen argued that unspecified "homosexual groups" undertook "a broad-based effort to embarrass her" in the mid-1980s. During a 1984 Senate hearing, she took aim at the North American Man-Boy Love Association (NAMBLA) - likely one of the "homosexual groups" to which she had referred earlier - and blamed the controversial organization for her son's disappearance. "Information . . . has surfaced during the investigation" into Johnny's presumed abduction "to indicate organized pedophilia operations in this country in which our son perhaps is a part of it [sic]," Noreen Gosch testified. Although the hearings focused on pornography's effects on women and children, broadly conceived, much of the witness testimony concentrated on child sex abuse, and media attention fixated on the phenomenon of man-boy sex. A segment airing nationally on $\mathrm{ABC}^{\prime} \mathrm{s}$ World News Tonight devoted considerable time to NAMBLA and its putative role in the Gosch kidnapping. When asked to explain why she believed NAMBLA might have taken her son, Noreen Gosch pointed to instructional literature distributed within the organization, which some identified as one of several "clearinghouses for information on child pornography." Gosch included with her testimony an issue of NAMBLA's Bulletin that made numerous mentions of her son's disappearance. The publication urged Johnny Gosch to "PHONE HOME!" and encouraged all runaway youngsters to call the National Runaway Youth Hotline, both to "relieve anxiety at home

43. KCCI-TV, 9/29/1982; Frank Santiago, "Leader of The Way: We Didn't Kidnap John Gosch," DMR, 10/9/1982. 
and resolve the question about the conditions under which leaving occurred." The Bulletin also expressed dismay that the public perceived NAMBLA to be "well informed" on issues related to runaway youths, calling that conception "both wrong and being used by the FBI against us." Indeed, the FBI zeroed in on NAMBLA in the early phases of the missing children campaign, and the organization criticized what it considered the "continuing efforts" of law enforcement "to blame boy-lovers for the disappearance of children, [and] to portray boy-lovers as bad guys and the police as good guys." NAMBLA representatives also denied the group's participation in "any illegal activities including the production and dissemination of 'kiddie porn' or the transportation of minors across state lines for 'immoral purposes,' or indeed any connection to exploitative operations that may involve young people." 44

For Noreen Gosch, the very fact that the FBI placed NAMBLA in its crosshairs deserved scrutiny, as did NAMBLA's reliance on the Fifth Amendment. Among "a great many other crude articles involving sex with men and boys," she advised, the Bulletin instructed NAMBLA "members not to submit to questioning regarding the disappearance, kidnaping of our son Johnny." Senator Arlen Specter (R-PA) asked for clarification: "And in the course of that publication there is a suggestion that your son Johnny is in [NAMBLA's] custody?" Noreen Gosch did not respond directly to Senator Specter's question but alluded again to NAMBLA's noncompliance with the FBI. “They are vehemently opposing any type of questioning, so this did arouse our suspicion," she explained. "We have, through Senator [Charles] Grassley's [R-IA] office and Senator [Roger] Jepsen's [R-IA] office, requested information from the FBI as to why they visited NAMBLA

44. Frank Santiago, "Noreen Gosch Denies Assault," DMR, 8/28/1984; ABC, World News Tonight, 8/8/1984, Vanderbilt Television News Archive, Vanderbilt University, Nashville (hereafter cited as VTNA); "JOHN GOSCH - PHONE HOME!" NAMBLA Bulletin 4, no. 5, June 1983, 3, in U.S. Congress, Senate, Committee on the Judiciary, Effect of Pornography on Women and Children: Hearings before the Subcommittee on Juvenile Justice, 98th Cong., 2nd sess., 8/8/1984, 9/12/1984, 9/25/ 1984, 10/18/1984, 10/30/1984, 80; Editorial, NAMBLA Bulletin 4, no. 5, June 1983, 2, ibid., 79 (emphasis in original). NAMBLA has been a lightning rod for controversy since its inception in 1978, but no evidence suggests that the organization has ever endorsed or facilitated the abduction of minors for sexual purposes. 
regarding our case. What was the reason to suspect them in the first place? ... We have not got that resolved as yet." She further lamented in a prepared statement, "When I was a child the major threat to children was 'POLIO' [;] that has been changed[;] it is no longer that disease[;] we now have something new which is growing at an alarming rate in this country. The danger is 'PEDOPHILE's' [sic]." 45 Many others involved in the missing children campaign shared Noreen Gosch's understanding of abduction and pedophilia as "new" and demonstrative of social and sexual liberation gone awry. Such discussions of nonconformity shed light on the disappearances - not just of Gosch and Martin, but also of Eberle and Walden - as events that shattered midwestern perceptions of "normalcy."

ONE OMAHA NATIVE writing in 2002 conflated the Gosch, Eberle, and Walden incidents and described the terror they inflicted on her idealized midwestern community. The Johnny Gosch disappearance, author Rainbow Rowell recalled, brought national concerns about child abductions to the Midwest, while the Eberle and Walden tragedies delivered them directly to her doorstep, "Right here. In Bellevue." Her "parents clamped down tight" and forbade her from entering public restrooms alone. Fears of "white slavery," AIDS, nuclear holocaust, and other threats, Rowell averred, deprived Omaha youngsters of a part of their childhoods. "Omaha kids stopped feeling like kids that year," she wrote. "We felt like prey. Scared all the time. Every car-or God forbid, van - that drove by us too slowly.... Our nightly prayers filled up with new anxieties. Please God, protect me from kidnappers. And rapists. And people who put AIDS-infected needles in phone booth change slots. And if I am kidnapped and raised in another state, please help me to remember my real name and phone number, so that someday, after the kidnappers start to trust me, I can call 911." For Rowell, neither her childhood nor her previously secure midwestern environs could save her from the dangers that seemed to be gathering around her. ${ }^{46}$

45. Committee on the Judiciary, Effect of Pornography on Women and Children, 70-71. 46. Rainbow Rowell, "Another Summer of Fear for Kids," Omaha World-Herald, 9/4/2002. 
The Gosches used the Omaha cases to advance their claims about law enforcement ineptitude. "The amount of publicity my husband and I generated brought faster action to the boys in Bellevue," Noreen Gosch claimed in March 1984. "The city of Omaha has just suffered two terrible tragedies. In that case, the police acted immediately. The FBI got involved right away. The reason there was such prompt action was because there had been a great many mistakes in our case." 47

The authorities had taken to ignoring Noreen as she sharpened her attacks against them. As the Gosches turned to private investigators and publicly castigated law enforcement efforts, West Des Moines police chief Orval Cooney fired back, on the record, in early 1983. "I really don't give a damn what Noreen Gosch has to say. I really don't give a damn what she thinks. I'm interested in the boy [Johnny] and what we can do to find him. I'm kind of sick of her." The tensions spilled over into a West Des Moines city council meeting, during which attorneys representing the Gosches and Polk County aired their respective grievances. After the hearing, both sides took the conversation outside. In the bitter January cold, Noreen Gosch engaged in a heated exchange with the Polk County attorney. As the lawyer gesticulated, Noreen reprimanded him, "Don't shake your finger at me!" In letters to elected officials and in other writings Noreen later denounced Cooney as an incompetent alcoholic, calling him, among other things, a "known drunk" and the "town drunk." 48

Throughout 1983, the Gosches developed an impressive campaign to help find their son, a movement they positioned within the burgeoning national child safety apparatus and against the traditional mechanisms of investigative police work. John and Noreen sold candy bars, buttons, and raffle tickets for a miniature race car to raise money for the investigation. A year after Johnny's disappearance, a television news report noted, the

47. Stern, "Mrs. Gosch: Iowa Errors Helped in Sarpy."

48. Frank Santiago, "Anger Flares as Gosch Hunt Drags," DMR, 1/2/1983; West Des Moines City Council Proceedings, tape 143, side A, 000 to 729, 1/3/1983, in author's possession; KCCI-TV, 1/3/1983; John and Noreen Gosch to Iowa State Representative Virgil E. Corey, 12/22/1983, "Missing Children" folder, N41/8/3, box 8, Departmental and Subject Files, Gov. Terry Branstad Papers, SHSI-DM; Gosch, Why Johnny Can't Come Home, 5. 
Gosches could still be seen "on any given night" at Des Moines area shopping malls, grocery stores, or community events distributing flyers imprinted with their child's face. Noreen appeared in the TV segment, accompanied by her husband, and stridently shared an anecdote about a woman who asked her if she was "embarrassed" by selling candy bars. "I said, 'I'm appalled that in this country, where we have 'Save the Seals,' 'Save the Whales,' and 'Save the Battleship' funds, that we don't have something for missing children,' but I said, 'We'll do whatever's necessary to find our boy. So embarrassed? No. Appalled? Yes.' " 49

These efforts and the populist rhetoric deployed to support them gained traction among Iowans and midwesterners. Many individuals who did not personally know John and Noreen Gosch volunteered in the search for Johnny, dedicating their time to raise money, attend meetings, distribute flyers, and write letters. A woman named Jeanne Wunn walked across Iowa with her two German shepherds to benefit the Help Find Johnny Gosch Fund. In one news clip, she wore a "HELP FIND JOHNNY" trucker hat as she slowly trudged along a deserted highway in the bleak mist, flanked by her dogs and followed by her husband in a rusted pickup truck. The pastoral scene evoked Iowa's agricultural tradition and a sense of statewide unity. To solicit donations, Wunn sold her dog's puppies and named them after the places through which her walk passed. Wherever the Wunns stopped, they circulated petitions and screened a documentary about missing children. Ultimately, the walk raised nearly $\$ 5,000$ for the Gosch fund-specifically, to hire and keep on private investigators. ${ }^{50}$ Noreen Gosch and her husband also developed an abduction awareness presentation, called "In Defense of Children," which they delivered hundreds of times across Iowa and the Midwest in the early 1980s.

SUCH PUBLICITY EFFORTS elicited passionate responses from ordinary Iowans who believed that Johnny Gosch's disappearance represented a blight on their state and revealed a threat to their

49. KCCI-TV, n.d. [1983] (emphasis added).

50. KGAN-TV, 5/2-5/1983, clip no. 312, AIB; KCCI-TV, 5/5/1983; Frank Santiago, "Walk, Dog Add \$4,700-Plus to Gosch Fund," DMR, 5/18/1983. 
communities. Iowans joined the Gosches in adopting the rhetoric of childhood, vigilantism, and region to petition for changes in state and federal laws pertaining to missing children. Influenced by these and other mobilization strategies, Iowa state legislators proposed in 1983 and passed in 1984 Senate File (S.F.) 517, also known as the Johnny Gosch Bill. The legislation established a taxonomy of missing children and required law enforcement agencies to respond "as soon as practicable" to a report of a missing child. 51

In letters to Iowa Governor Terry Branstad, who had been inaugurated in early 1983, Iowa mothers pleaded for governmental action on missing children. "My daughter Allyson and I attended a meeting last night on child safety," Carolyn Schultze noted. "The speaker was Noreen Gosch. What she said angered and shocked me. Our children are a very special gift and should be protected" through "greater involvement and interest by State and Federal employees." Shirley Frette from Story City explained in a letter to the governor how "fortunate" she "was . . to hear Mrs. Norene [sic] Gosch speak in [her] community about the statistics on this problem" of child abduction and molestation. She continued, "God is speaking through her to alert us of the growing operation of molesters and abductors." Frette excoriated public officials while encouraging vigilantism on the part of embattled parents. "I was amazed, shocked, and downright furious that this problem is being taken so lightly by the police force, FBI and government officials. . . If our government officials won't take a stand on this issue then it is up to us, as parents, to protect the innocent victims, our children." Finally, Frette struggled to grasp whether tragedies like the Gosch disappearance occurred in places like Story City, a town of 2,762 in 1980. "I have never heard of any incidents of this nature in Story City. Could it possibly be that this never happens here? I doubt it." For Frette, the Gosch case united West Des Moines and Story City and illustrated that no community was safe from the scourge of child kidnappings. Carolyn Heuser from Manson also alerted the governor to the ubiquity of the missing children problem. "I have one

51. Ch. 1084, Investigations of Missing Persons, S.F. 517, Acts and Joint Resolutions passed at the 1984 Regular Session of the Seventieth General Assembly of the State of Iowa, approved 4/13/1984, 117-18. 
question which is really bothering me and I suppose many many other concerned parents and citizans [sic] of Iowa," she wrote. "'How can we make our laws stricter and punishment more severe on child abductors'?... This is a very real and severe problem and getting worse all of the time. We are in a small community but very aware that we are not immuned [sic] to such crime." 52

Other mothers from small Iowa towns presented similar views about the state's duty to protect children as well as the ways the Gosch case refashioned their roles as parents. Ellen Burton from Madrid urged Governor Branstad to support S.F. 517. "I want all of Iowa's children to have a safe place to live," she wrote. "We need stiffer pentally [sic] and more thorough investigation of these cases. This is a real fear of myself and many here in my community. We are voters [and] our children will one day vote." Referring to the youngsters of Madrid as citizens and future voters, Burton employed children's rights to protection and, in a sense, political representation to frame her argument. ${ }^{53}$ In a letter to her state senator, Debbie Carlson of Webster City likewise explained how the Johnny Gosch disappearance, and the proposed bill that followed it, at once affected her children, state, and nation. "As a concerned parent of three children," she asserted, "I am aware of the growing threat of abductions in this state and the entire country. I believe the passage of Bill 517 is crucial to Iowa and especially it's [sic] children.... Hopefully this law would be an important deterrent to anyone considering Iowan children an easy target." 54

These missives evinced an anxiety shared by parents across the nation. But Iowa parents, more so than those in other parts of the country, concentrated on statehood and region in their

52. Carolyn M. Schultze to Gov. Terry Branstad, 5/18/1984, Constituent Correspondence (McK-Z), box 2, Almo Hawkins files (1983-84), Branstad Papers; Shirley Frette to Gov. Terry Branstad, Feb. 1984, ibid.; Carolyn Heuser to Gov. Terry Branstad, 5/5/1983, ibid.

53. Ellen Burton to Gov. Terry Branstad, 12/12/1983, Constituent Correspondence (McK-Z), box 1, Almo Hawkins files (1983-84), Branstad Papers. For more on this "slippage" between the ideal child and citizen, see Lauren Berlant, The Queen of America Goes to Washington City: Essays on Sex and Citizenship (Durham, NC, 1997).

54. Debbie Carlson to State Sen. C. Joseph Coleman, 12/4/1983, Constituent Correspondence (McK-Z), box 1, Almo Hawkins files (1983-84), Branstad Papers. 
conceptualizations of the missing children program. Furthermore, it was mostly mothers who wrote to Branstad on the issue, suggesting that Noreen Gosch's experience resonated with Iowa's women more than its men. Perhaps Johnny's disappearance challenged their prescribed positions as guardians of the household at a time of shifting gender roles; in this reading, these women supported S.F. 517 because it offered a safety net for Iowa mothers, an instrument by which the state could intervene to keep intact the "traditional" American household. Women also might have felt more comfortable than men in asking for state protection for their children. 55

Advocates of the Johnny Gosch Bill hoped it would fortify the Iowa home against the dangers and perversions that confronted it. One state senator diagnosed the "sickness" that legislators sought to counteract with the bill's passage in the spring of 1984. "We live in a sick and rotten society that is getting sicker and rottener every day. I don't know what's happened to the United States, but it has become more animalistic, not more humanistic in recent years." 56 This yearning for a bygone America, one devoid of the "sickness" and "rottenness" that ostensibly wrought the Gosch disappearance and other such tragedies, appeared in the broader national discourse as well. But the Gosch case offered a particularly captivating study in "normality" purportedly crushed by external forces. Media scholar Victoria E. Johnson has explored the ways prime time television in the late twentieth century deployed the mythic image of the Midwest as a site of serenity, ordinariness, whiteness, and heteronormativity devoid "of urbanity, people of color, and non-agrarian industry." 57 Those mythic images converged in popular conceptions of the Gosch disappearance.

Although media accounts regularly depicted child abductions and murders in other parts of the country as "tragic" and evidence

55. As an analog, see Linda Gordon, Heroes of Their Own Lives: The Politics and History of Family Violence (New York, 1988). Gordon shows how heightened concerns over domestic violence corresponded with spikes in feminist consciousness in the 1880s, 1890s, and 1960s.

56. Tom Witosky, "Bill Requiring Faster Responses to Missing Children Reports Passes," DMR, 3/1/1984.

57. Johnson, Heartland TV,19. 
of a "sickness" threatening American children, they did not portray the places in which those cases occurred as somehow impervious to larger national trends. In fact, it was commonly understood that the urban settings of the 1979 Etan Patz kidnapping and Atlanta youth disappearances and murders of 1979 to 1981 explained, at least partially, why they happened. According to newspaper and television reports, Patz, a six-year-old who vanished from his Manhattan neighborhood, fell victim to the widespread criminal depravity coursing through New York City at the time. ${ }^{58}$ In Atlanta, some accounts held, the South's gothic racism and a national resurgence of conservatism could be blamed for the slayings of nearly 30 poor African American youngsters. One Los Angeles Times piece addressed the early 1980s political milieu and the "black nihilism," to use Cornel West's term, that it engendered. "Now, more than in a long time, blacks feel the depression that comes with the rise of the Ku Klux Klan, the violent, unsolved killings of blacks, the erosion of civil rights, the bleak economic picture and, most recently, the election of a conservative President and a much more conservative Congress." 59 Southern color writer and Atlanta resident Lewis Grizzard, a white man, rejected that view but underscored its potency. Racism became "the logical explanation," he opined, for these cases of "black children being murdered in a major southern city. . . . Behind every Atlanta building and tree, the world was led to believe, there lurked the hooded menace." 60

Whereas many African Americans worried that the Atlanta killings marked a return to the racial violence of years past, some white Americans envisioned Johnny Gosch as the embodiment of white America, a fictive tradition now under siege by deviance and social change. A write-up in the Chicago Tribune in mid-1983 stressed the symbolic weight of the Gosch case. "By all accounts, Johnny was indeed the all-American boy," the article affirmed.

58. See, for instance, Kyle Riismandel, "Under Siege: The Discursive Production of Embattled Suburbs and Empowered Suburbanites in America, 1976-1992" (Ph.D. diss., George Washington University, 2010), esp. 95-96.

59. Cornel West, Race Matters, 1st ed. (New York, 1994); Lee May, “More U.S. Blacks Are Singing the Blues," Los Angeles Times, 11/27/1980.

60. Lewis Grizzard, editorial, ABC, Nightline, 3/1/1982, audio tape recording, box 90, Series VII: Videos and audiocassettes, LPB. 
Noreen Gosch advanced a similar idea in the piece: "Paperboys symbolize the all-American boy," she noted. "I guess when this happens to these kids, it hits a little too close to home." The story also quoted James Gannon, editor of the Des Moines Register, who painted West Des Moines as a community that should be exempt from such tragedies. "This case sends home the message that if you're not safe in West Des Moines in a nice neighborhood, you're not safe anywhere." 61

Such nostalgic formulations advanced a narrow view of white American boyhood. Their racial, class, sexual, and regional implications would become even more apparent after Eugene Martin's disappearance. In Noreen Gosch's rendering, it was perversion and depravity that jeopardized the idyll of a protected, white, middle-class, midwestern childhood. At the aforementioned 1984 Senate hearing on the "effect of pornography on women and children," she lamented, "We lived in a nice quiet neighborhood in which one would least expect this type of tragedy to occur." Gosch diagnosed her son's alleged kidnapping as a symptom of national moral failings. "I think that we must begin to realize that we are living in a society in this country that has been programmed to believe: If it feels good, do it. If you want it, take it." 62 Her testimony took direct aim at the libertinism and narcissism that, according to her, was shaking the country from its moorings.

WHEN EUGENE WADE MARTIN WENT MISSING on August 12, 1984-just days after Noreen Gosch had addressed the Senate hearing - it again fixed national attention on the Des Moines area. Like Johnny, the 13-year-old Martin-effortlessly handsome, appearing both boyish and mature-had set out to deliver the Sunday Register in the early morning hours and never returned. ${ }^{63}$ Right away, Iowans drew parallels between the incidents and conjectured about what they meant for their children,

61. Eileen Ogintz, "'.. . If You're Not Safe in W. Des Moines ...'” Chicago Tribune, 6/20/1983.

62. Committee on the Judiciary, Effect of Pornography on Women and Children, 70, 68.

63. Tom Alex, "Missing Paper Carrier Is Believed Kidnapped," DMR, 8/13/1984; Frank Santiago, "Martin Case Is a Photocopy of Disappearance of Gosch," DMR, 8/16/1984. 
communities, and region. In a feature on ABC's World News Tonight, Donald Martin, Eugene's father, quietly spoke into the camera. "I'm afraid of what I think now. I think we got another deal like that poor Johnny Gosch setup." Noreen Gosch, in the same news segment, concurred. "They're disappearing rapidly. Our child, the Martin child ... it's the same story repeated all over the country." Yet the news story also accentuated the distinctively "all-American" landscape in which these events occurred. Standing before a row of boxy police cruisers in Des Moines, reporter Karen Burnes declared, "But it's hit home this time. These are Iowa's paperboys." Back in the New York studio, anchor Peter Jennings introduced the piece by waxing nostalgic: "It wasn't so long ago in this country that having your own newspaper route was part of the American dream. It's an early way to learn responsibility and earn a little pocket money at the same time. It has not been that way in Des Moines, Iowa. Karen Burnes explains why." 64 This enmeshment of childhood, regional, and historical innocence-under-siege revealed itself again and again in local and national news coverage. Within these depictions, of course, resided particular assumptions about race, sex, gender, and class. Comparisons between Gosch and Martin abounded, but no one seemed willing to interrogate their similarities along those vectors.

Gosch and Martin were both white, middle-class, midwestern, suburban paperboys, all descriptors that allowed them to be rendered innocent and vulnerable in the popular imagination. Literary theorist Kathryn Boyd Stockton ably analyzes the white, middle-class, asexual childhood that Americans seek "to safeguard at all costs." Stockton and others have identified Americans' fascination with innocence and youthful purity. Innocence itself, in this view, can be understood as an alternate sexuality celebrated by adults who no longer possess it. 65

\section{ABC, World News Tonight, 8/13/1984, VTNA (emphasis added).}

65. Stockton, The Queer Child, 30. See also Lee Edelman, “The Future Is Kid Stuff: Queer Theory, Disidentification, and the Death Drive," Narrative 6 (1998), 18 30; James Kincaid, Erotic Innocence: The Culture of Child Molesting (Durham, NC, 1998); Judith Levine, Harmful to Minors: The Perils of Protecting Children from Sex (Minneapolis, 2002); Anne Higonnet, Pictures of Innocence: The History and Crisis of Ideal Childhood (New York, 1998). 
Media accounts imbued the paperboys "with more meaning than [they could] possibly hold," and in the process, the youngsters shouldered the anxieties of a region. After Eugene Martin vanished, Register editor James P. Gannon published a searing editorial that illustrated the symbolic heft Iowans gave the paperboy cases. "Somebody has singled out Des Moines, Iowa, for a special brand of terror," he opened. "Here, in the normally safeand-sane heartland of middle America, where clean living, neighborliness and a sense of security are supposed to prevail, a sinister shadow darkens our doorways and our lives." These incidents, Gannon proclaimed, "raised questions that violate everything we hold dear about living in this comfortable, contented community: Is it no longer safe to let our youngsters walk our neighborhood streets? Will Des Moines, as if it were Detroit or Newark or Chicago, shut itself behind closed doors and cede the streets to the shadowy threat of terror?" 66

The editor's "light versus dark" formulation and denunciation of American cities with lengthy histories of racial unrest suggest other dichotomies as well: rural versus urban; white versus black; safe versus dangerous. For Gannon, the Martin disappearance disproved once and for all "the 'it can't happen here' myth." The national media had seized on the issue, he bemoaned, and challenged the midwestern idyll. "The television networks and the national press are fascinated with an unlikely tale: terror in Des Moines, of all places. We are on display, each one of us bit players in a drama that examines what's wrong in a place that's supposed to be so right." Because of that, Gannon insisted, "We should be mad as hell." The editorial touched on familiar themes. Gannon posited a collective midwestern trauma inflicted by the paperboy disappearances and identified an anticrime populism as the appropriate response. In addition, the presumed abductions challenged the fundamental tenets of midwestern identity.

66. James P. Gannon, “Commentary: The Dark Threat of Terror Now Stalking D.M. Should Make Us All 'Mad as Hell,' " DMR, 8/15/1984. In "The Era of Lost (White) Girls: On Body and Event," Differences 19 (2008), 101, literary scholar Rebecca Wanzo argues that media outlets obsessed over white and telegenic missing girls in the 2000s and, in turn, "reconfigured and imbued" the female body "with more meaning than she can possibly hold." That body, she continued, became "a powerful symbol through the carefully crafted representation of her disappearance or death." 
"I didn't move my family to Des Moines to live in fear behind locked doors," Gannon continued. "I do not cede the night to shadowy figures who hide by day. I do not accept the notion that my children's freedom of movement is a daytime right only. The sun should never set on freedom and personal security," two rights that he implicitly linked with Des Moines and, by extension, the Midwest. ${ }^{67}$

Other Iowans echoed Gannon's claims. "The citizens of Des Moines and surrounding areas should be mad. We should be mad as hell," Scott B. Neff of Des Moines wrote in a letter to the Register. "This city and this geographical area are supposed to be comfortable, safe places to raise children, work and lead productive lives. This entire situation tarnishes every citizen in this community. Kidnappings, murders, rapes and this type of terrorism should be a call to arms and a call to anger for all law-abiding citizens." Neff conceived of the Gosch and Martin episodes as blemishes on the Midwest that should mobilize the region's residents to combat "this type of terrorism." Paul Jackson of Sioux City agreed. These "newspaper-boy crimes ... have stained the city of Des Moines. ... Let us roll up our sleeves and go to work on crime prevention by biting the bullet now!" William Peterson from Iowa City also took the paperboy disappearances as a call to action and framed citizens' anticrime initiatives as an existential imperative. He implored his fellow Iowans, "Join a neighborhoodwatch program, or better yet, start one. This has been going on in some neighborhoods as a method of survival in Des Moines for years. Now the whole city needs to watch. We all can and should take more responsibility to protect our children." 68

CITIZENS' SAFETY PROJECTS, like those promoted by William Peterson, cropped up throughout Iowa in the early 1980s.

67. Ibid. Gannon's use of "mad as hell" invokes the famous line from the 1976 feature film Network, which became a touchstone for politically disaffected Americans in the mid- to late seventies. Network, dir. Sidney Lumet (1976). For a popular history of the 1970s that deploys the "mad as hell" ethos as an organizational schematic, see Dominic Sandbrook, Mad as Hell: The Crisis of the 1970s and the Rise of the Populist Right (New York, 2011).

68. Letters to the editor, DMR, 8/29/1984, 9/5/1984 (emphasis added). 
Neighborhood watch programs first gained widespread popularity in the late 1960s, but only in the early to mid-1980s did the current vision of "community crime prevention" take hold as a cooperative enterprise between law enforcement and ordinary citizens. ${ }^{69}$ After Gosch went missing and even more so after Martin vanished, Des Moines residents organized neighborhood watch squads. "Children can't even play in the [neighborhood] by themselves," one father from eastern Des Moines declared to justify his local crime prevention program. ${ }^{70}$ By September 1984, according to President Ronald Reagan, each of Iowa's 99 counties had "established a crime prevention Citizen's Watch program," which he praised as "an accomplishment that few States can match." 71 Whether or not the Gosch and Martin disappearances catalyzed these initiatives, it is safe to assume that they played a strong role in their development.

The local child safety infrastructure that the Gosches helped to establish following their son's disappearance expanded after Martin's. A month after Eugene Martin vanished, the Iowa State Patrol introduced a program called Stranger Danger. It comprised "a talk by a patrol community service officer, a film and free wallet-size cards with safety tips" for children. A patrol chief cited "concern arising from the apparent abductions of Des Moines news carriers Eugene Martin and Johnny Gosch" as the program's impetus. About two months after Martin went missing, the Johnston police department launched a similar project, dubbed Operation Kids, which intended "to acquaint parents, children, merchants and school officials with the dangers facing children and how to deal with them." The Des Moines Register promoted its H.O.P.E. program with greater fervor following Martin's disappearance, dedicating large advertising spots in the paper to raise awareness about the initiative. The paper also published public

69. Dennis P. Rosenbaum, “Community Crime Prevention: A Review and Synthesis of the Literature," Justice Quarterly 5 (1988), 323-95; see n. 47 for antecedents to these programs.

70. Kay Logan, “Child Watch Program Set on East Side,” DMR, 7/11/1984.

71. Ronald Reagan, "Remarks at a Reagan-Bush Rally in Cedar Rapids, Iowa," American Presidency Project, 9/20/1984, presidency.ucsb.edu/ws/?pid= 40407\#axzz2j1cL4U5h, accessed 4/19/2013. 
service announcements asking locals to "leave an outdoor light on for your Des Moines Register carrier." 72

Amid this growing concern for child safety, Governor Branstad organized a conference in November 1984 called Children in Jeopardy, billed as "the only gathering of its kind in the nation." Many of the state's top policymakers attended the conference, one newspaper article observed, "to defuse some land mines that threaten to explode the notion that Iowa is a safe place for children." By arranging the event, Branstad hoped to demonstrate that "the state might be ready to get tough" on crimes against children. The conference pressed for stricter background checks on those who worked with young lowans, as well as harsher penalties for child molesters. Conference organizers also underlined the importance of developing a "public and a private partnership" between business and government. ${ }^{73}$ That "partnership" could be seen in the milk carton campaign triggered by the paperboy incidents and in corporate programs dedicated to "keep children safe" from abduction, molestation, and general corruption. President Reagan consistently encouraged such initiatives, perhaps because they cast the private sector in a positive light. ${ }^{74}$

While Gannon, Branstad, and other Iowans embraced anger and organized civic initiatives in an attempt to trump their fear, others seemed resigned to the "sick society" that the paperboy disappearances ostensibly unearthed. Parents took their children off their paper routes, monitored their play in neighborhoods as never before, and had them walk in front of them in shopping

72. "Child Safety Program Set," DMR, 9/22/1984; "Happenings: Operation Kids Program Planned," DMR, 10/10/1984; H.O.P.E. advertisement, DMR, 8/22/ 1984; Public service announcement, DMR, 11/11/1984.

73. Frank Santiago, "Leaders Meet to Tackle Issues of Child Safety," DMR, 11/25/ 1984.

74. For more on President Reagan's promotion of private-sector responses to the missing children problem, see U.S. Congress, Senate, Private Sector Initiatives Regarding Missing Children: Hearing before the Subcommittee on Juvenile Justice, 99th Cong., 1st sess., 5/22/1985; Ronald Reagan, "Remarks at a White House Luncheon for the Presidential Board of Advisors on Private Sector Initiatives," 1/22/1986, Public Papers of Ronald W. Reagan, Ronald Reagan Presidential Library, reagan.utexas.edu/archives/speeches/1986/12286d.htm, accessed 6/19/ 2013; "Remarks at a White House Meeting with Members of the National Newspaper Association," 3/7/1985, Public Papers of Ronald W. Reagan, reagan.utexas.edu/archives/speeches/1985/30785a.htm, accessed 6/19/2013. 
malls, lest an abductor snatch the child from behind their backs. ${ }^{75}$ For many Iowans, the Gosch and Martin cases heralded a crisis of childhood, parenthood, and statehood. One mother lamented to the Des Moines Register that her "three young boys ... are being deprived of their youth"; another called the disappearances "a blight on the state of Iowa ... a utopia for murderers and kidnappers because it will not impose the death penalty for these crimes." (The state had outlawed the death penalty in 1965.) For Karl Schilling of Des Moines, the city's inhabitants needed to "show the country" that they "are concerned for one another." Roger Corbin of Traer, Iowa, wrote to the Register "only because of the need I feel to say and/or do something about the shameful problems we have with missing children here in Iowa. I'm sure this problem exists in other areas as well, but it tugs at the heart more here when it hits close to home." 76

The Martin disappearance hit particularly close to home for Iowa's young paperboys and girls. A 1984 national television news segment on ABC's World News Tonight underlined the fears among the state's young carriers while portraying their craft as both idealized and endangered. "The newspaper boys are still missing," Peter Jennings segued from a previous feature. His blunt hook implied that Americans were following the Gosch and Martin cases with considerable interest. In the field, reporter Karen Burnes praised the newspaper carriers who courageously kept their routes and delivered papers in pairs rather than alone. She called them "reliable as always" but remarked that the "fear of kidnapping is so deeply etched in this community now that some will not even allow their faces to be photographed." The subsequent frame showed only the back of an adolescent, clad in a ball cap and hooded sweatshirt, speaking to Burnes. He tried to grapple with the enormity of the situation. "This has happened twice now, and [it] could happen again, so ..." Burnes interviewed an even younger paperboy next. His bright blond locks and summer tan made him the picture of boyhood innocence, but he trembled imagining the horrors he might endure as an abductee. "Oh, I don't know what I'd do if somebody kidnapped me because it' $\mathrm{d}$

75. Melinda Voss, "Recent Tragedies Take Toll on Parents Trying to Protect Children," DMR, 8/19/1984.

76. Letters to the editor, $D M R, 9 / 11 / 1984$. 
be kinda scary 'cause they might kill me or take me away and then brainwash me or something. I'd never see my family again." 77

Others saw the paperboy cases as signs of a national immorality now seeping into Iowa's suburbs. "Another child has been snatched from our streets," Irish Cowell from Sioux City bemoaned. "Why? We are obsessed with sex! Nothing pinpoints its vulgarities and sadist pleasure more than the porno material. Our children have become victims of untold horrors for the explicit purpose of bringing joy to those who receive their monthly publication." Cowell echoed Noreen Gosch's condemnation of pornography as a likely cause of Johnny's disappearance. Carolyn Keown from Des Moines faulted pornography but also religious cultism, as Noreen Gosch had earlier, for the moral depravity supposedly gripping the country. "As a parent, I raise my 15year-old to believe that the world is a good and just place. Now it makes you wonder if it is still good and safe. You could never have told me when I was 15 years old that people are like they are now. So many just don't care for one another. There are so many wicked, perverted people. So many religious cults. So much hatred for each other. So much pornography involving children." Larry Riley from Perry concurred. "This is one sick country. Our morals and spiritual values are practically nonexistent. When are tougher laws going to be made for the crime of child molesting?" 78

Even though no definitive evidence ever emerged linking child pornographers, pimps, or predators to the Gosch or Martin disappearances, the notion that both paperboys fell victim to a seedy underworld of child prostitution remains a plausible explanation for many Iowans. Consistent with this view, there have been numerous reported sightings of both paperboys throughout the United States since 1982, particularly in the South and Southwest.79 Many seem unwilling to consider that the boys

\section{ABC, World News Tonight, 8/14/1984, VTNA.}

78. Letters to the editor, $D M R, 9 / 2 / 1984$.

79. For examples of such sightings, see Frank Santiago, "Family Reports Nine Sightings of Gosch Youth," DMR, 6/25/1983; Steve Kline, "Newspaper Carrier Cases Eerily Similar," AP news release, 9/25/1983; "Report: Child Kidnapped in 1982 Sighted," AP news release, 1/30/1984; Mark Mittelstadt, "Johnny Gosch's Mother Says Her Son Seen in South," AP news release, 2/23/1984; 
simply ran away or that one or more locals stalked, abducted, and possibly murdered Gosch and Martin. Perhaps by transferring blame onto a faceless monster like a child prostitution ring or a religious cult operating outside-or even within - the Midwest, Iowans could absolve their region, their state, and their community from any culpability.

Either way, the paperboy cases belied notions of midwestern exceptionalism and convinced many that Iowa was not immune to the national forces threatening their children's innocence. In a November 1984 poll of 602 Iowa adults, two-thirds of respondents agreed that young Iowans were "less safe ... than they were five years ago," before the Gosch and Martin disappearances. Nearly nine out of ten parents surveyed attested that they were "more strict and cautious in the supervision of their own children as a result of the [Gosch and Martin] kidnappings" and other cases of child exploitation. ${ }^{80} \mathrm{~A}$ "climate of fear," one newspaper story observed, enveloped West Des Moines, Johnny Gosch's hometown. "The mood of uneasiness shows itself in several ways," the article continued. "Many children are no longer allowed to walk to school alone. ... Several neighborhoods have started procedures to 'track' neighborhood children as they play at different homes. ... Children who were once warned against trusting strangers are now drilled on the subject by parents who stage examples of how strangers might try to get children into a car." 81 The boys' disappearances had transformed Iowa childhood and parenthood.

These regionally tailored anxieties made it all the way to the Oval Office. President Reagan seized upon the Gosch and Martin tragedies and positioned them within his rhetorical appeals to family, law and order, and midwestern exceptionalism. ${ }^{82} \mathrm{He}$

Margaret Stafford, "Parents Keep Working to Find Missing Son," AP news release, 3/3/1984; Frank Santiago, "Martin Look-Alike Is Reported Hitchhiking in Washington State," DMR, 9/19/1984; idem, "Possible Martin Sighting Likely Another Mistake," DMR, 10/31/1984; idem, "Noreen Gosch: I Saw Johnny," DMR, 2/7/1999; idem, "Johnny Gosch's Dad Questions that His Ex-Wife Saw their Son in 1997," DMR, 2/8/1999.

80. David Elbert, "Poll Finds Fear for Safety of Children on Rise in Iowa," DMR, $11 / 25 / 1984$.

81. Anne Carothers-Kay, "Climate of Fear in W.D.M.," DMR, 10/31/1984.

82. For more on law and order politics and the ways it helped undermine the New Deal order, see Michael W. Flamm, Law and Order: Street Crime, Civil Unrest, 
phoned Register editor James Gannon soon after Eugene Martin went missing, extending his "regrets and sympathies" and assuring Gannon that he would "get right on it." "Thank God we've reached the Ivory Tower," Noreen Gosch exclaimed in response to Reagan's phone call. "Thank God they recognize that our kids are in danger." 83 At a campaign stop in Cedar Rapids the following month, Reagan deployed the Gosch and Martin cases, situating them within a romanticized vision of Iowa history. "This was open prairie," he proclaimed. "And then the pioneers began to settle here: Yankees, Germans, Swedes, Norwegians, and immigrants from many other nations - men and women as hardy as the land. They ploughed the sod, they planted crops, they dotted the land with farmhouses and built lovely towns like Cedar Rapids. And soon, Iowa contained some of the richest farmland in history, feeding tens of millions in America and around the world." Reagan then wedded this triumphal past with 1980s America. "As our economy grows, we'll need to go forward with the bedrock values that sustained the first Iowa settlers and that nourish us today. And they're the simple values of faith, family, neighborhood, and good, hard work. And we're already making a good start." To actualize these values, he implored, "We must continue cracking down on crime. We say with no hesitation ... there are such things as right and wrong. And yes, for hardened criminals preying on our society, punishment must be swift and sure." 84 Reagan vowed to get "tough on crime" and rejected the culture of permissiveness that had, in his formulation, sanctioned criminal predation.

Iowa was facing this scourge of crime just as other places were, Reagan implied, but things were improving under his leadership. "There've been two tragedies in Iowa that have saddened us all," he lamented. "In 1982, young Johnny Gosch disappeared while delivering newspapers on his morning route in

and the Crisis of Liberalism in the 1960s (New York, 2005). For a discussion of how Cold War ideas about family, crime, and security have shaped American life since World War II, see Elaine Tyler May, "Security against Democracy: The Legacy of the Cold War at Home," Journal of American History 97 (2011), 939-57.

83. Frank Santiago and Tom Alex, "Reagan Calls to Offer Aid on Missing Boys," DMR, 8/17/1984.

84. Reagan, "Remarks at a Reagan-Bush Rally in Cedar Rapids, Iowa." 


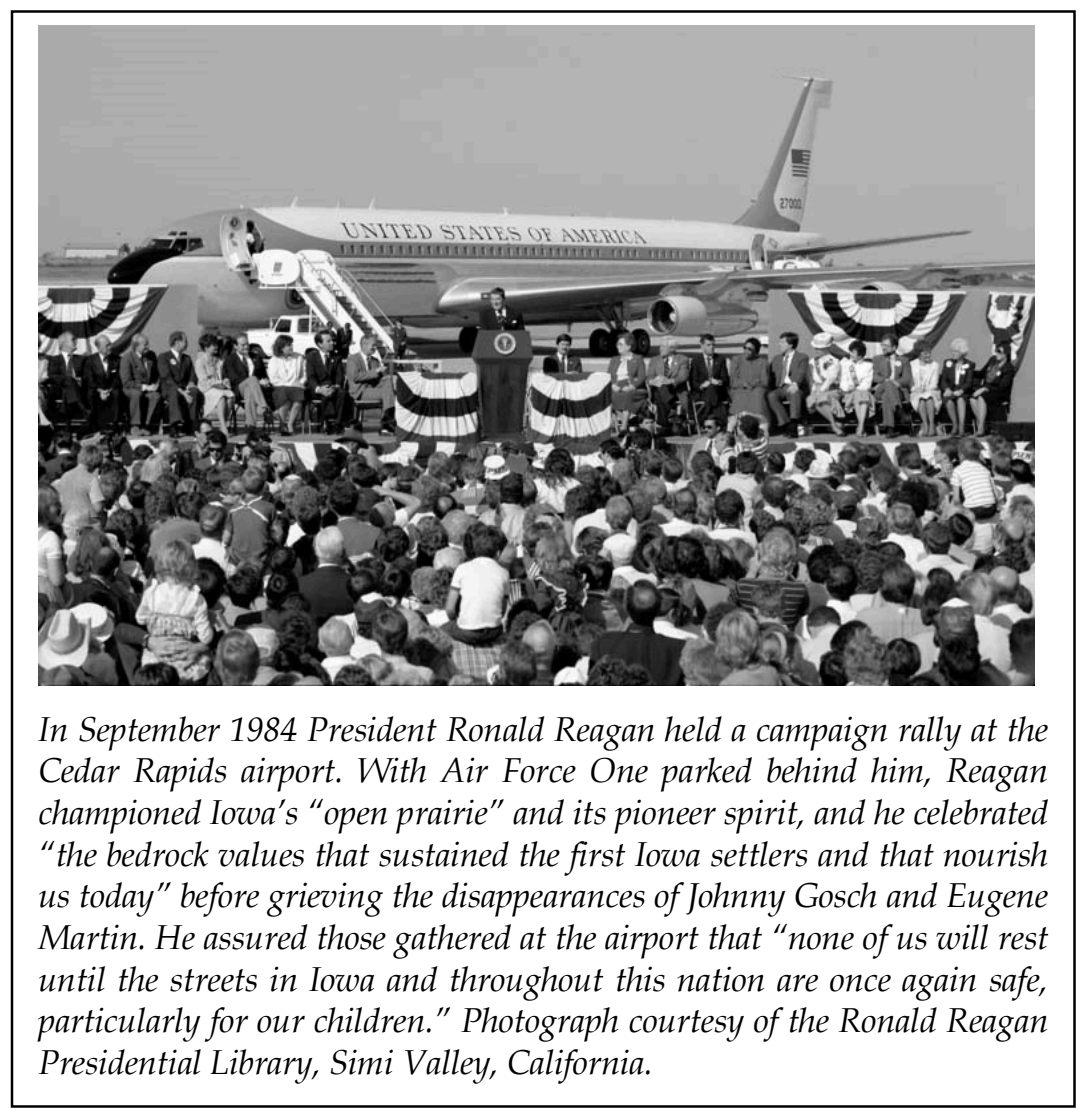

Des Moines. Then, just [six] weeks ago, another newspaper boy, Eugene Martin, also disappeared." The president then reassured his audience,

Well, I want you to know that I've spoken with Jim Gannon, the editor of the Des Moines Register. We've pledged our full support in the search for these two boys. And this past June, we established the National Center for Missing and Exploited Children in Washington [D.C.] to help locate missing children across America. So far, the Center has received thousands of telephone calls and helped hundreds of parents. Nancy and I join all of you, I'm sure, in praying for the safe return of Johnny and Eugene. And I pledge to you that none of us will rest until the streets in Iowa and throughout this nation are once again safe, particularly for our children. ${ }^{85}$

85. Ibid. 
Reagan juxtaposed Iowa's rich farmland with its crime-infested "streets" and upheld the virtues ascribed to the state's pastoral tradition. While he maintained that Americans "need to go forward with the bedrock values that sustained the first Iowa settlers," he actually advocated a return to that "open prairie" undergirded by "faith, family, neighborhood, and good, hard work."

THE NOW ICONIC MILK CARTON CAMPAIGN initiated soon after Eugene Martin went missing also drew heavily on notions of midwestern pastoralism and traditionalism. Des Moines's own Anderson-Erickson Dairy pioneered the program in response to the paperboy disappearances. Taking cues from the child safety infrastructure that developed in Iowa after Johnny Gosch vanished, including the Register ads and eighteen-wheelers featuring photographs of both missing paper carriers, AndersonErickson began printing milk cartons with the boys' faces on them in September 1984. The following week, Prairie Farms Dairy, also headquartered in Des Moines, started doing the same on the side panels of their milk cartons. Although these first efforts stimulated little media attention, other milk processors around the Midwest soon helped the campaign - which eventually featured missing youths from all over the country - gain traction nationwide. ${ }^{86}$

By January 1985 the project had entered the national consciousness, as stories about the milk cartons appeared in the Chicago Tribune, Los Angeles Times, and the New York Times, and on ABC's and CBS's nightly news programs. ${ }^{87}$ Both the ABC and CBS reports underscored the midwestern setting from which the milk carton campaign emerged. "In various cities across the continent, parents in search of their children have thought long and hard of ways to keep their missing children's image in the public eye," Peter Jennings explained. "One very dramatic idea appears to

86. Richard R. Kerr, "Processors Unite to Help Children," Dairy Field, April 1985, 46-53. For truckers' efforts to publicize the paperboy disappearances, see KGANTV, 5/7-9/1984, clip no. 480, AIB; "Truckers to Aid Gosch Search," DMR, 5/8/ 1984; "Cross-Country Eye-Catcher," DMR, 9/15/1984.

87. John Kass, "Milk Cartons to Carry Missing Kids' Pictures," Chicago Tribune, 1/1/1985; Lenore Look, "Missing Youngsters: Milk Cartons Join Hunt for Children," Los Angeles Times, 1/18/1985; Andrew H. Malcolm, “Milk Carton Snapshots Delivering a Warning," New York Times, 1/29/1985. 
have started in the Midwest, and, as Gary King reports, it is now an idea which is spreading." With the help of the Chicago police department, a nowdefunct Illinois dairy, modeling its program after AndersonErickson's, brought the milk carton program onto the national stage. Because the dairy sold two million milk cartons per month in Illinois, Iowa, Wisconsin, and Indiana, the issue of missing children-inscribed on dairy products - became symbolically tied to the American Midwest. 88 By February 1985, with the endorsement of the National Child Safety Council, more than 600 dairies were participating in the campaign. At the program's peak, an estimated three to five billion milk cartons carried missing children's photographs. Similar programs were also discussed or instituted as far away as Australia, Sweden, and Great Britain. 89

In conceptualizing, pro-

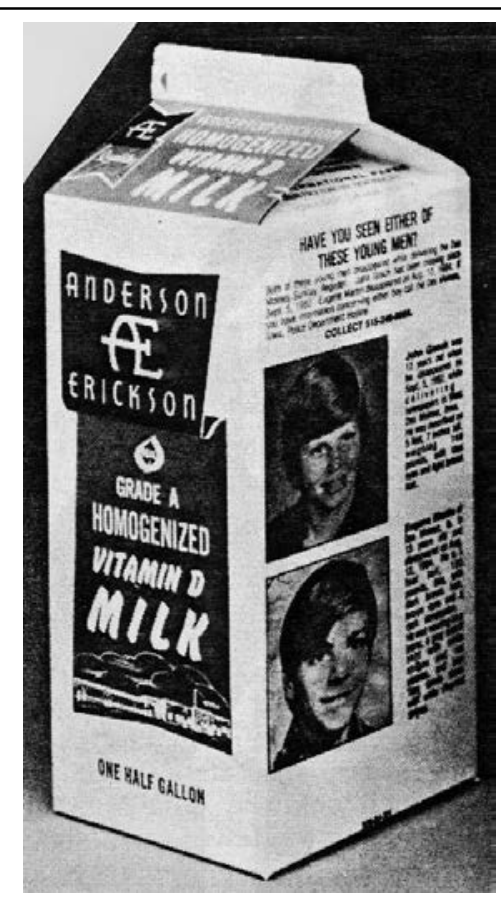

Anderson-Erickson Dairy was the first to place missing children's photographs on its milk cartons, and Johnny Gosch and Eugene Martin were the first youths pictured in this way. The above image originally appeared in Richard $R$. Kerr, "Processors Unite to Help Children," Dairy Field, April 1985. Courtesy of BNP Media. ducing, and distributing these milk cartons, midwestern dairies provided a script for use in American kitchens. The products offered families a chance to

88. ABC, World News Tonight, 1/16/1985, VTNA; CBS, Evening News, 1/1/1985, VTNA; ABC, World News Tonight, 1/16/1985, VTNA.

89. Robert M. Andrews, “Milk Cartons: New Role," New York Times, 2/13/1985; Eleanor Blau, "Follow-Up on the News: Pictures of Children," New York Times, 10/5/1986; ABC, Good Morning America, interview with Walter Woodbury, n.d., [1985?]; ABC, World News Tonight, 1/16/1985, VTNA; Vicki Quade, "Missing Kids: Milk Cartons Help the Hunt," American Bar Association Journal 71 (1985), 28. 
discuss over a glass of milk or a bowl of cereal the plight of missing youths and to develop guidelines to ensure their children's safety, thereby connecting the American home with the idealized midwestern landscape from which the cartons originated. However, dairies discontinued the practice in the mid-1980s because it frightened children and failed to return missing youngsters to their homes in significant numbers..$^{90}$ Still, that dairy processors evoked midwestern landscapes and farming traditions-and that milk connoted youthful innocence and health - can partially explain why the short-lived milk carton project sparked such interest and why it still resonates today. ${ }^{91}$

The milk carton programs that Gosch and Martin's disappearances helped activate ultimately informed new means by which activists publicized the missing children cause, from the ubiquitous "Have You Seen Me?" leaflets mailed nationwide by ADVO, Inc. (now Valassis) to Walmart's Code Adam campaign and the Department of Justice's AMBER Alert initiative. ${ }^{92}$ Through their

90. Rick Bowers, "Milk-Carton Photos Cited for Scaring Kids," Miami Herald, $1 / 11 / 1986$.

91. See, for instance, Caroline B. Cooney's popular young adult novel The Face on the Milk Carton (New York, 1990); Alice Sebold's bestselling novel The Lovely Bones (New York, 2002) and its 2009 film adaptation by the same title; The Lost Boys, a 1987 "teen horror" film; and rapper Eminem's music video for "The Real Slim Shady" (2000). For more on "scriptive things," see Robin Bernstein, "Dances with Things: Material Culture and the Performance of Race," Social Text 27 (2009), 67-94; idem, Racial Innocence: Performing American Childhood from Slavery to Civil Rights (New York, 2011). For more recent examples of milk cartons as a cultural and political touchstone, see photo illustrations by Lauren Nassef for Lori McIlwain, "The Day My Son Went Missing," New York Times, 11/13/2013; and Mauricio Alejo for Ed Caesar, "Too Hot to Handle," New York Times Magazine, 11/17/2013, table of contents, 4. Special thanks to Landon R. Y. Storrs for bringing these recent examples to my attention. For just one more example, in a January 1988 Democratic presidential primary debate hosted in Des Moines, candidate and former Arizona Governor Bruce Babbitt addressed Al Gore's twomonth absence from Iowa: "Al, it's good to see you back. You know, I thought they might start putting your picture on milk cartons." The auditorium and Babbitt's fellow presidential hopefuls met the joke with laughter, but the jab "brought protests from the parents of missing children," including Noreen Gosch, who chided, "I think it's in bad taste. Why should he make fun of it? To us, it's a big deal." ABC, World News Tonight, 1/16/1988, VTNA; Marcia Dunn, "Babbitt Blames 'Spontaneity' for Inappropriate Joke," AP news release, 1/17/1988.

92. For more on these and other undertakings, see Marilyn Ivy, "Have You Seen Me? Recovering the Inner Child in Late Twentieth-Century America," Social Text, no. 37 (Winter 1993), 227-52; Eric Freedman, "'Have You Seen This Child?' 
use of children's photographs, these efforts since the early to mid-1980s have transfixed the American public and transmitted powerful messages about lost childhood innocence and the need to protect American youths.

THE GOSCH AND MARTIN CASES continue to loom large in the Iowa consciousness. They fractured, at least in the public imagination, a pristine past. As one outsider shrewdly observed, the disappearances belonged within a series of tribulations that left Iowans "tenuous in a time of change." Indeed, before the early 1980s, "Iowans were relaxed in a rural atmosphere where doors could be left open, keys left in the ignition and kids left out to play on the lawn. Problems could be isolated, defined, confronted and solved. Then corporations began to buy out family farms, debts exploded and newspaper boys began to disappear." 93 The Gosch and Martin disappearances fused together with the farm crisis to define a moment of human misery in the Midwest. Today, activists and politicians on either side of the death penalty debate continue to invoke the boys' names. ${ }^{94}$ Noreen Gosch remains a proponent of state and federal mechanisms intended to thwart child abductions. Other parents who have endured similar losses have emulated her activism. Iowans Heather and Drew Collins began "crusading for quicker community notification when children disappear" after their daughter Elizabeth was kidnapped and murdered in 2012. They also articulated their "concerns over sex offenders who have shirked their registration requirements." 95

Theories regarding Gosch and Martin still abound. In 1991 Noreen Gosch went public with information provided to her by

From Milk Carton to Mise en Abyme," in Eric Freedman, Transient Images: Personal Media in Public Frameworks (Philadelphia, 2011), 25-52; and Perry Howell, "Got Worry? Missing Children Notices on Milk Cartons in the United States," Interactions: Studies in Communication $\mathcal{E}$ Culture 2 (2010), 35-46.

93. Mitch Gelman, "On the Road to the Future, but Where Does it Lead?" DMR, $11 / 4 / 1984$.

94. For just a few examples, see Rod Boshart, "Petitioners Back Capital Punishment," Cedar Rapids-Iowa City Gazette, 9/7/1994; idem, "Death-Penalty Foes Speak," Cedar Rapids-Iowa City Gazette, 2/27/1997; MacKenzie Elmer, "Lawmaker Seeks Death Penalty Bill," Dubuque Telegraph Herald, 1/26/2013.

95. Jeff Reinitz, "1 Year Later: Collins Family Remains Active after Disappearance of Elizabeth, Lyric," Waterloo-Cedar Falls Courier, 7/12/2013. 
a private investigator concerning a "child-sex ring of four men" that had "planned and carried out the abduction of her son." Those men, she insisted, might have also been "involved in other abductions, including [Eugene] Martin's and the October 1989 kidnapping of Jacob Wetterling in St. Joseph, Minn." 96 Conspiracy theories about Gosch specifically have flourished online since the 1990s. A quick Internet search yields myriad websites on which skeptics implicate the government, and specifically the first Bush administration, in an organized child prostitution syndicate, based at an Omaha credit union, that allegedly stole Johnny. ${ }^{97}$

Iowans have their own stories about the Gosch and Martin mysteries. In one way or another, their names mean something to the state's children and adults. Fully 99 percent of Iowans polled in 1984 said they had "read or heard about" Johnny Gosch and Eugene Martin. Thirty years later, the cases remain central to Iowans' conceptions of crime, security, childhood, and region. ${ }^{98}$ For many, the two separate yet interconnected tragedies caused the state, the region, and its children to lose at least a modicum of their innocence, freedom, and charm. Frank Santiago, the primary Register journalist assigned to the Gosch case, ruminated on its significance in 2012. "We're talking about the early 1980s. Kids were out playing in the dark. Their moms let them go to school unescorted. This was a part of Americana for a long, long time, and it's gone, and it started with those two stories." Also in 2012 a Des Moines television reporter offered a similar reflection on Iowa exceptionalism. "I think people thought, 'I can't believe this could happen here.' I mean, this kind of stuff doesn't happen here." 99 The Gosch and Martin disappearances may not have actually transformed Iowa, but many people believe that they did. Examining these cases, their representations, and the attitudes they fostered enables us to look closely at the ways we construct myths: about our communities, our homes, our families, our children, and the political fabric that stitches them together.

96. $\mathrm{AP}$, “Johnny Gosch: Family, Investigators Disagree on Evidence," Daily Iowan (University of Iowa, Iowa City), 7/22/1991.

97. Erin Crawford, “Is He Johnny Gosch?” DMR, 4/5/2005.

98. Elbert, "Poll Finds Fear for Safety of Children on Rise in Iowa."

99. Missing Johnny, MSNBC. 